\title{
Kirjoituksia eletyistä ja kerrotuista elämistä
}

Maarit Leskelä-Kärki: Toisten elämät: Kirjoituksia elämäkerroista. Helsinki: Avain, 2017, 272 s.

"Kirjoittamisen muotona elämäkerta on erottamaton osa inhimillistä olemassaoloa. Meillä on tarve kertoa elämästä ja tulla itse kerrotuiksi”, kirjoittaa kulttuurihistorian dosentti Maarit Leskelä-Kärki teoksensa Toisten elämät: Kirjoituksia elämäkerroista $(2017,17)$ johdannossa. Vastaavasti haluamme lukea toistemme elämistä, mistä kertovat niin erilaisten ääni- ja e-kirjasovellusten top-listat kuin kirjojen myyntitilastotkin. Toisten elämissä Leskelä-Kärki selvittää elämäkertakirjoittamisen historiaa ja sen kulttuurihistoriallisia merkityksiä. Teos on suunnattu akateemisia lukijoita suuremmalle yleisölle, mikä osaltaan tekee siitä helposti lähestyttävän ja rakenteeltaan selkeän. Kirjan loppuun lukukohtaisesti kootut kirjallisuusluettelot palvelevat aihepiiristä laajemmin kiinnostunutta lukijaa.

Toisten elämät pohjautuu Leskelä-Kärjen aikaisempaan tutkimustyöhön ja julkaistuihin tutkimusartikkeleihin pääpainon ollessa kotimaisessa elämäkertakirjoittamisessa. Kotimainen traditio kytkeytyy erityisesti pohjoismaiseen mutta myös laajemmin länsimaiseen kontekstiin. Ajallisesti se kattaa kotimaisen elämäkertakirjoittamisen historian 1800-luvun lopun varhaisista pioneereista 2010-luvulle. Näin kronologisesti etenevässä teoksessa hahmottuvat niin lajityypin historiallinen kehityskaari kuin sille kunakin aikana tyypilliset konventiot.

Laajassa aineistossa elämäkerrallisuus ilmenee eri muodoissaan kulttuurin läpäisevänä ilmiönä. Kirjallisten elämäkertojen ja elämäkerrallisen fiktion ohella teoksessa käsitellään myös elokuvan, teatterin ja musiikin keinoja esittää elämäntarinoita. Yksi kiehtovimpia esimerkkejä onkin brittiläisen Goldfrappyhtyeen konseptialbumi Tales of Us (2013), jonka kymmenessä kappaleessa kerrottua kymmentä, joko todellista tai fiktiivistä, elämäntarinaa rakentaa albumin kokonaistoteutus fyysisen levyn visuaalista ilmettä ja viidestä kappaleesta kuvattua lyhytelokuvaa myöten.

Leskelä-Kärjen Toisten elämät keskittyy ennen kaikkea naisten kirjoittamiin ja naisista kirjoitettuihin elämäkertoihin. Rajaus on perusteltu. Kuten teoksen kirjoittaja huomauttaa, elämäkerta lajina on ollut vahvasti sukupuolittunut: alkujaan elämäkerta on nähty merkittäville, esikuvallisille henkilöille - eli useimmiten miehille - varattuna lajina. Tarkastellessaan elämäkertaa sekä sen kehitystä ja kulttuurisia merkityksiä naistoimijoiden kautta Leskelä-Kärki huo- 
mioi elämäkertojen kirjoittajina tunnetuksi tulleiden tekijöiden lisäksi myös monia tuntemattomampia ja elämäkertakirjoittamisen marginaaliin jääneitä kirjoittajia ja elämäkertojen kohteita, sekä alleviivaa 1800-luvun lopun ja 1900luvun alkupuoliskon ei-akateemisen elämäkertakirjoittamisen merkitystä naisiin keskittyvälle historiankirjoitukselle. Kotimaisen elämäkertakirjoittamisen osalta teoksen päämielenkiinto vaikuttaakin olevan nimenomaan ajassa ennen yliopistoissa tehtävän naisten historiaa käsittelevän tutkimuksen yleistymistä.

Pääasiallisesta rajauksesta huolimatta miehiä niin tekijöinä kuin elämäkerrallisen kirjoittamisen kohteina ei ole täysin jätetty teoksen ulkopuolelle. Oleellista on, että Leskelä-Kärki näkee nämä aineistoon sisällyttämänsä kirjailijat ja teokset - kuten Erik Wahlströmin perinteistä suurmieskuvastoa murentavat elämäkertaromaanit sekä Juha Viikilän elämäkerta- ja päiväkirjaromaanin konventioita sekoittavan Akvarelleja Engelin kaupungista (2016) - tavalla tai toisella poikkeuksellisina niin elämäkerran kuin elämäkerrallisen fiktionkin traditioissa. Kenties teosta hallitsevan naisnäkökulman takia jään kuitenkin ihmettelemään sitä, että lopulta Leskelä-Kärjen teoksesta jää kaikumaan sitaatti Karl-Ove Knausgårdin massiivisen Taisteluni-sarjan päättäneestä kuudennesta osasta. Näin siitäkin huolimatta, että kyseessä on epäilemättä yksi 2000-luvun omaelämäkerrallisen kirjallisuuden suurimmista tapauksista ja että kyseissä sitaatissa Knausgård kirjoittajan mukaan "tuo esiin yhteytemme toisiin ihmisiin, mikä voi tulla esiin nimenomaan tarinoiden kautta" (244), mikä osaltaan kyllä kiteyttää myös Toisten elämien ydinviestiä, eli kertomisen ja kerronnallisuuden merkitystä yksittäisten elämien oikeuttajana ja olevaksi tekijänä.

Sukupuolen tai sukupuolittuneisuuden ohella yksi keskeisiä toistuvia teemoja Leskelä-Kärjen teoksessa on menneisyydestä ja historiallisista henkilöistä kirjoittamiseen liittyvä kysymys vallasta ja vastuusta. Elämäkerran kirjoittajalla on valta valita kenestä elämäkerran kirjoittaa, kenestä ei. Tällaiset valinnat ovat aina myös paitsi kulttuurisia, myös yhteiskunnallisia ja poliittisia: ne kertovat siitä historiallisesta ajasta ja yhteiskunnallisesta kontekstista, jossa elämäkerta on kirjoitettu - ja tähän myöhemmin tapahtuvat luennat lisäävät aina oman kerroksensa. Juuri tämänkaltainen näkökulman rikastaminen on yksi selittävä tekijä sille, miksi Leskelä-Kärki antaa teoksessaan tilaa myös elämäkerrallisesta tuotannostaan tuntemattomammille kirjailijoille ja elämäkertojen kohteille.

Valta kuvastuu myös elämäkerran kirjoittajan ja kohteen suhteessa, joka väistämättä muodostuu erilaiseksi kuin historiallisista tapahtumista kirjoitettaessa. Suhde on useimmiten hyvin henkilökohtainen ja siihen voi liittyä samastumisen ja empatian kaltaisia tunteita, mikä ei kuitenkaan sulje pois kriittisyyttä elämäkerran kohteena olevaa kohtaan. Elämäkerta on väistämättä elämäkerran kirjoittajan tulkintaa henkilöstä, jonka elämästä kirjoittaa. Kirjoittajalla on tulkinnallinen valta kohteensa elämään, mutta yhtä lailla häntä sitoo vaade esittää kohde autenttisena ja totuudenmukaisena. Leskelä-Kärki kirjoittaakin historioitsija Merja-Liisa Hinkkaseen viitaten pieteetistä, kunnioituksesta mennyttä, historiallista henkilöä kohtaan (219). 
Leskelä-Kärki korostaa teoksessaan myös, ettei elämäkerran kirjoittaminen ole ainoastaan toisen ihmisen elämän taltiointia, vaan myös elämäkerran kirjoittajan henkilökohtainen projekti, jossa elämäkerran kirjoittaja, kohde ja tätä koskeva tutkimustyö sekä elämäkerrallisen kerronnan traditiot lomittuvat toisiinsa (239). Tällä tavoin ymmärretty henkilökohtaisuuden aspekti ilmeneekin monissa Toisten elämien aineistona olleissa elämäkerroissa, mutta myös teoksen kirjoittajan analyyseissa ja tulkinnoissa niistä.

Kuvaavaa onkin, että sivumäärällisesti laajimman huomion teoksessa saavan kirjailijan, Aino Kallaksen, elämäkerrallinen tuotanto käsittää ainoastaan yhden teoksen, virolaisen runoilijan Lydia Koidulan elämäkerran. Loppujen lopuksi onkin mahdollista esittää kysymys, onko Leskelä-Kärjen Toisten elämät niinkään alaotsikkonsa mukaisesti kirjoituksia elämäkerroista vai pikemminkin aineistona olevien elämäkertojen kirjoittajista. Henkilökohtaisesti kallistun jälkimmäisen vaihtoehdon puoleen.

Heta Marttinen 